\title{
PERSPECTIVES ON GRADUATE EMPLOYABILITY ATTRIBUTES FOR MANAGEMENT SCIENCES GRADUATES
}

\author{
R. S. Shivoro* \\ e-mail: rshivoro@gmail.com
}

\section{R.K. Shalyefu*}

e-mail: rkshalyefu@unam.na

\section{N. Kadhila*}

e-mail: nkadhila@unam.na

*University of Namibia

Windhoek, Namibia

\section{ABSTRACT}

Universities need to take stock of the current state of graduate employability from both the employers' and the graduates' perspectives if they are to respond effectively to the knowledge and skills requirements of the industry. Globally, graduate employability is a concept that is becoming increasingly popular in the higher education sector. The underlying assumption is that graduates need attributes other than those skills needed in the subject-specific discipline. This article provides an assessment of stakeholders' perceptions on graduate employability attributes for management sciences graduates in Namibia. The study applied a survey method, with questionnaires being administered to the three types of stakeholder, namely, employers, lecturers and graduates. The study found a mismatch in responses between these stakeholders regarding the attributes that are important for the job market, those that are emphasised in curricula, and those that graduates need more training on. The argument presented by the article is that mapping stakeholders' perceptions will enable universities to equip their graduates with employability attributes needed by the industry.

Keywords: Graduate employability; labour market; higher education; human capital; graduate attributes; employability skills

\section{INTRODUCTION}

Graduate employment patterns seem to have changed worldwide (Tran 2016). The labour market is inundated with graduates with similar qualifications competing for graduate jobs. In addition, organisations and companies are shrinking their workforce due to unpredictable and inconsistent economies. It is therefore clear that the labour market has become competitive and flexible. These changes have been caused by the expansion of higher education provision, 
globalisation, and the expansion of the global economy, which are influencing the hiring needs of employers (Al-Harthi 2011; Cai 2013; Tran 2016). For employers, the decision to hire a graduate is based on the graduate's qualities and abilities in addition to discipline-specific knowledge and skills. Brown and Hesketh (as cited in Tomlinson 2008) note that employers are relating the employability discourse to behavioural competence and the wider range of personal, performative and organisational abilities. To this end, universities and students alike have become aware of the changing nature of employment patterns, and are working to incorporate employability attributes in degree programme provision (Cai 2013). This realisation has led to studies to determine what employability attributes are sought after by employers in a given context.

In Namibia, as elsewhere, employers' concerns about graduate employability attributes have become more pronounced (Links 2010; National Council for Higher Education 2011; Schade and Amunkete 2011). There are claims from various stakeholders, especially employers, that graduates from universities often do not fully possess the types of graduate employability attributes essential for the workplace. Marope (2006) notes that there is a general impression that diverse employers are dissatisfied with the quality of higher education output. This observation is echoed by the Namibian National Council for Higher Education (2011), which states that university graduates are often not adequately prepared for work, and that the training is not relevant to the needs of the workplace. In reference to higher education, the National Human Resource Plan document has identified a critical challenge facing human resources development in Namibia. This challenge includes the inadequate attention paid to the development of graduate employability attributes, which has a negative impact on the preparedness of university graduates for high-skilled jobs (National Planning Commission 2010).

Although employers in Namibia have raised concerns about the lack of employability attributes in graduates, no study has investigated the issue of the employability attributes that are important for job performance; those attributes that should be to be included in curricula; and those in which graduates need more training. Therefore, the aim of this article is to analyse the need for graduate attributes in Namibia, as perceived by graduates, employers and lecturers, using the discipline of management sciences as a case. The article argues that assessing the needs of higher education stakeholders provides an understanding of which graduate attributes should be enhanced by higher education institutions (HEIs) in order to boost employability prospects of graduates.

In exploring the topic of graduate attributes, it is useful to look at the related literature on 
university education and the economy, conceptualising graduate employability attributes, stakeholders in graduate employability, and the types of attributes sought after by the labour market elsewhere.

\section{UNIVERSITY AND THE ECONOMY}

The link concerning university education and the economy, specifically the labour market outcomes, can be well explained using human capital (HC) and signalling theories. Research on HC has established that higher education is an investment for productivity in the labour market (Fincher 2007; Jonck 2014). This is supported by (Cai 2013, 3) who states that ‘education increases individuals’ productivity, which consequently enhances job performance'. This investment is manifested by an increase in abilities that subsequently increase throughput and growth of organizations. In addition, Weber (2014) notes that persons with more education are likely to be in a position to adjust more easily than those with less education. In other words, higher education avails sought-after capabilities that are relevant for succesfull execution of tasks. Therefore, individuals who have obtained more knowledge and skills stands a better chance to be more successful in work, and receive better remuneration, and they are more likely to receive more job offers than those with lesser knowledge and skills (Weber 2014). Equipping individuals with more knowledge and skills contributes to the quality of work assigned to them; more rewards to them in the form of income, more employment opportunities, and a financial comfortability (Kaplan and Norton 2004). Melink and Pavlin (2012) substantiate that education is an investment process geared towards prospect of better life earnings.

Like HC, signalling theory (Stiglitz 1975, as cited in Cai 2013) assumes a relationship between graduates seeking a job and the employers. Based on this theory, a graduates applying for a job sends a signal of their capabilities to prospective employers, by showcasing knowledge and skills they have acquired in university. Prospective employers assess the application to determine graduate's abilities. Therefore, the graduate's portfolio of knowledge and skills is treated as a determinant of quality expected from the applicant. This perspective assumes that higher education is simply an apparatus for graduates to indicate the capabilities they possess to those that are hiring. Rospigliosi, Greener, Bourner and Sheehan (2014) write that the industry identifies individals with innate marketable qualities that are hard to observe, by looking at their educational achievements. This view regards education as a window to observe inborn qualities of a graduates, rather than a process of developing knowledge and skills that are needed for productivity in the industry. Therefore, a higher education qualification is a strong indicator of the job-seekers innate abilities and projected labour market outcome. 
The two views on the relationship between the university and industry have provided justification for the importance of graduate employability attributes. Graduate attributes are necessary in the $21^{\text {st }}$ Century, taking cognisant of the knowledge economy, globalisation and the ever-changing conditions of the labour market (Yorke 2006). Therefore it is important that universities in general and in Namibia in particular align learning provisions to address the labour market requirements by enhancing employability attributes. Conceptualising graduate employability therefore warrants deeper scrutiny.

\section{CONCEPTUALISING GRADUATE EMPLOYABILITY ATTRIBUTES}

Graduate qualities and skills are conceptualised differently by different universities and higher education systems. Terminologies commonly used are words such as transferrable skills, key skills, soft skills, generic attributes, employability skills, key competencies, core skills, and underpinning skills. In most cases, these terms are used interchangeably to refer to graduate employability (Tempone et al. 2012).

The concept of graduate employability encompasses a simplistic and holistic view on the qualities of a graduate in a community. According to Hillage and Pollard (1998, 2) 'employability as the ability to gain initial employment, maintain employment and obtain employment if required'. Bowden, Hart, King, Trigwell and Watts, as cited in Bridgstock (2009, 32) go further to add the contribution of a graduate to the profession and the community as they define employability as 'the qualities, skills and understanding a university community agrees its students would desirably develop during their time at the institution and, consequently, shape the contribution they are able to make to their profession and as a citizen'. Yorke $(2006,8)$ provides a more abstract definition of employability as 'a set of achievements that comprise skills, understanding and personal attributes that make an individual more likely to secure and be successful in his/her chosen occupation to the benefit of him/herself, the workforce, the community and the economy'.

Employability is comprised of two main aspects: subject or discipline-specific skills, and transferrable skills. Wickramasinghe and Perera (2010) assert that subject skills are key to the graduate's career as they are discipline-specific knowledge and skills. They add that transferable skills are those competencies that a graduate can apply in many different job roles and professions through the graduate's career. However, Barrie (2006) provides a conceptualisation that has been considered as a lens for understanding the concept in this article, as they view graduate attributes as the attributes that graduates have acquired at university in addition to discipline-specific knowledge, which may be applied to varied contexts. Literature 
has not provided one agreed definition of graduate employability, therefore this article is written from the perspective of the latter conceptualisation.

\section{KEY STAKEHOLDERS IN THE GRADUATE EMPLOYABILITY DISCOURSE}

In different parts of the world studies have been conducted to ascertain the perceptions of students and/or graduates, lecturers and employers in industry. Some studies have focused on individual stakeholders, some a combination of two, and others a combination of the three types of stakeholder. What follows is a review of the literature related to graduate employability stakeholders

\section{Students/graduates}

The inclusion of students/graduates in the employability discourse is important as these are the key stakeholders in employability. As Tymon (2013) asserts, they are the primary recipients of employability attribute development and their views are therefore vital. It is thus necessary to ascertain whether their views on employability attributes are similar to or different from other employability stakeholders. Research has established that in the crowded and competitive graduate labour market, students and graduates are aware that the role of their academic qualifications in shaping employment outcomes is declining (Tomlinson 2008). Graduates are becoming increasingly aware that they need to add value by acquiring employability attributes to earn a competitive edge in the industry. In addition, graduates recognise the importance of graduate attributes developed through the university curriculum. Most students and graduates place particular importance on personal qualities (Moreau and Leathwood 2006; Crebert et al. 2004). In his study, Brown (2007) indicated that students have expressed confidence that their curriculum enhances a combination of relevant employability attributes necessary for job performance. Given the above, the general position is that students leave university with high hopes that the skills and attributes they have acquired at university are those that are sought by employers. However, it is important to establish whether graduates' views are in line with those of employers.

\section{Lecturers}

As stakeholders in the concept of graduate employability, academics in various universities have presented their views on graduate employability. A study by Morrison (2014) indicates that lecturers' views are that employers expect higher education institutions to provide graduates with employability attributes, specifically, critical thinking, ability to articulate, and 
self-confidence. The lecturers in this study expressed the opinion that graduates have poor standards of written communication than would be expected of university graduates. This is in contrast with Ahmadl, Suhaili and Shariati (2015), whose study found that lecturers perceive that the highest level of employability attributes graduates leave university with is communication skills, followed by information management, leadership, teamwork and, lastly, professional ethics. Contrasting results are a common occurrence in graduate employability research. In a study by Lowden, Hall, Elliot and Jon (2011) on the perceptions of higher education institutions, a list of graduate employability attributes and characteristics was generated including communication skills, taking initiative, working independently, creativity and problem solving, time management, networking, presentation skills, systems thinking, leadership skills, self-confidence, enthusiasm, and work ethics.

\section{Employers}

Like graduates and lecturers, employers in different countries have offered their perspective on graduate attributes. In scoping interviews with employers, Wimalasiri (2015) found that specific roles in a workplace require a combination of different transferable skills. Such qualities and attributes are working in teams, solving problems, managing oneself, understanding of the business, literacy and numeracy skills that are relevant the graduate's area key responsibilities, information communication technology skills, interpersonal relations, taking initiative, receptive to guidance, and leadership skills. While some employers found graduates to be highly competent in personal qualities and skills (Wye and Lim 2009), others found a high mismatch in attributes including critical analysis, organising, problem-solving, ability to articulate, decision-making, and influencing the process (Lowden et al. 2011).

Although prior to this study no study has been conducted in Namibia to determine attributes that are desired by the labour market, employers in other countries have prioritised and ranked employability attributes. For example, employers in Malaysia ranked personal qualities and interpersonal skills as highly important, and systems thinking and technology skills of lower importance (Husein et al. 2010; Omar et al. 2012). In New Zealand, a study by Hodges and Burchell (2003) found that employers' top five preferences inculde ability and willingness to learn; working in teams; good interpersonal relations; providing excellent service to clients; and being accurate, organised, and maintaining excellent standards. The same goes for the United Kingdom as Martin, Villeneuve-Smith, Marshall and Mckenzie (2008) list timekeeping, literacy and numeracy, eagerness and dedication, communication, and personal presentation skills as attributes most sought after by employers. In Australia, a study by 
Tempone et al. (2012) suggested that employers require graduates to possess communication, teamwork and self-management skills.

Although there seems to be agreement to a certain extent, the information presented here is isolated as it does not provide a direct comparison of graduates, employers and academic staff in a given profession or country. In an attempt to provide a comparison between stakeholders in one context, Rosenberg, Heimler and Morote (2012) found out that in that specific context, the most important attributes rated by graduates are leadership and work ethics. This differs from those of HEIs and employers who scored lower on this dimension. HEIs indicated that interpersonal skills are most needed for job performance, while employers perceive literacy and numeracy as most needed for job performance. Thus there is clearly a gap between attributes that are perceived to be important by employers, graduates and HEIs. This is affirmed by Griesel and Parker (2009), who concluded in a study in South Africa that graduate employability competencies enhanced by universities are in many ways incongruent with the requirements of the contemporary labour market. Given the difference in desired graduate employability attributes in other countries, it is appropriate to conclude that the labour market needs for attributes are contextual. Therefore, this study is significant in determining the perspectives of employers, HEIs and graduates in Namibia so that concerted efforts can be made to synchronise graduate skills with the needs of the labour market.

\section{TYPES OF GRADUATE EMPLOYABILITY ATTRIBUTE}

The literature on graduate employability has generated varying lists of the graduate attributes presumably required by the labour market. Although the lists differ in terms of categorisation and prioritisation of attributes, there does seem to be a certain degree of similarity.

The graduate employability attributes presented in Table 1 show that different agencies and universities prioritise attributes differently. Table 1 shows a considerable variation in the prioritisation of attributes. While some providers consider communication a priority, others lean toward critical thinking and teamwork. Therefore, it could be cumbersome for the higher education system to have an agreed framework. The table also shows that some attributes might be the same but worded differently. For example, ‘self-motivation' could be the same as ‘ability to work on your own', or 'self-management'. There is a need to consider that although the wording of attributes might vary the meaning might be the same. That being said, there is no substantial difference in the attributes presented in the table but the prioritisation of the attributes differs.

The varied lists of employability attributes have been amalgamated into eight dimensions 
as 'basic literacy and numeracy skills, critical thinking skills, leadership skills, management skills, interpersonal skills, information technology (IT) skills, systems thinking skills, and work ethics’ (Rosenberg, Heimler and Morote 2012, 8). The explanation provided below is taken from Kennedy (2010); Rosenberg et al. (2012) and Schermerhorn (as cited in Rosenberg et al. 2012, 11). These are explained as follows:

Table 1: Employability attributes in the literature - adopted from Markes (2006)

\begin{tabular}{|c|c|c|c|c|c|}
\hline $\begin{array}{l}\text { Middlesex } \\
\text { University } \\
(2003)\end{array}$ & AgCAS (2005) & $\begin{array}{l}\text { Heitmann } \\
\text { (2003) }\end{array}$ & Markes et al. (2004) & DfEE (2000) & $\begin{array}{l}\text { HEA } \\
\text { Engineering } \\
\text { Subject Centre } \\
(2005 a)\end{array}$ \\
\hline $\begin{array}{l}\text { - } \text { Personal and } \\
\text { career } \\
\text { - development } \\
\text { - } \text { effective } \\
\text { learning } \\
\text { - communication } \\
\text { - teamwork } \\
\text { - IT and } \\
\text { - numeracy. } \\
\text { Further surveys } \\
\text { have shown that } \\
\text { at the top of this } \\
\text { list (which usually } \\
\text { emphasises } \\
\text { - teamwork and } \\
\text { - written and oral } \\
\text { - communication) } \\
\text { is } \\
\text { - imagination } \\
\text { and creativity }\end{array}$ & $\begin{array}{l}\text { The ability to } \\
\text { analyse } \\
\text { information } \\
\text { critically and } \\
\text { produce creative } \\
\text { solutions to } \\
\text { problems: } \\
\text { - communication } \\
\text { and customer- } \\
\text { facing skills } \\
\text { - initiative-taking } \\
\text { - ability to work } \\
\text { on your own } \\
\text { and in a team } \\
\text { computing } \\
\text { skills and } \\
\text { technical skills } \\
\text { (CAD), visual } \\
\text { and spatial } \\
\text { awareness } \\
\text { (added to } \\
\text { these are: } \\
\text { foreign } \\
\text { language and } \\
\text { international } \\
\text { mobility, } \\
\text { knowledge of } \\
\text { industrial } \\
\text { processes and } \\
\text { techniques, 3D } \\
\text { conceptual } \\
\text { ability, } \\
\text { commercial } \\
\text { awareness, } \\
\text { coping with } \\
\text { pressure and } \\
\text { deadlines as } \\
\text { wegll as project } \\
\text { maills). } \\
\text { timanagement, } \\
\text { management } \\
\text { and effective } \\
\text { netiang } \\
\text { anage }\end{array}$ & 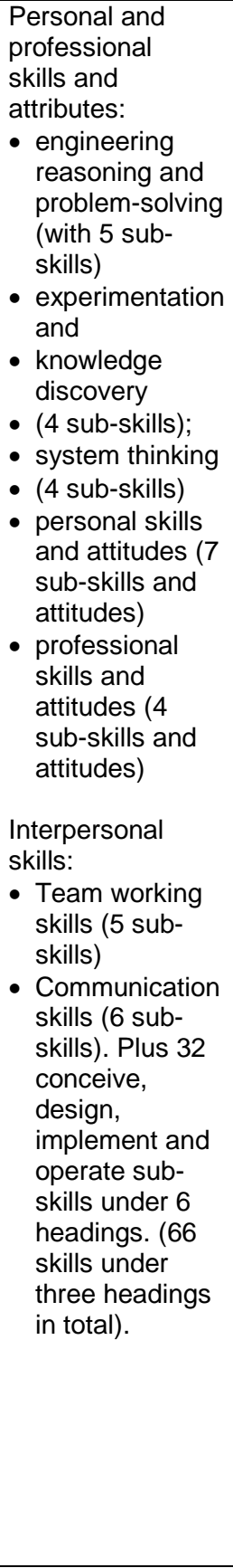 & $\begin{array}{l}\text { - Key skills } \\
\text { (communication, IT, } \\
\text { working with others, } \\
\text { application of } \\
\text { number, improving } \\
\text { own learning and } \\
\text { performance, } \\
\text { problem solving) } \\
\text { - Personal and } \\
\text { professional } \\
\text { development skills } \\
\text { (self-management, } \\
\text { organisational } \\
\text { management, } \\
\text { interacting with } \\
\text { others, professional } \\
\text { conduct/awareness, } \\
\text { intellectual skills) } \\
\text { - Technical skills } \\
\text { (core skills: } \\
\text { tendering, } \\
\text { managing costs, } \\
\text { project } \\
\text { management, } \\
\text { technical reports, } \\
\text { technical drawings) } \\
\text { - Personal attributes } \\
\text { (Adaptability, } \\
\text { assertiveness, } \\
\text { creativity, initiative- } \\
\text { taking, motivation } \\
\text { and resilience). } \\
\text { Software RAPID - } \\
\text { developed by } \\
\text { Loughborough } \\
\text { University: 62 skills } \\
\text { in total. }\end{array}$ & 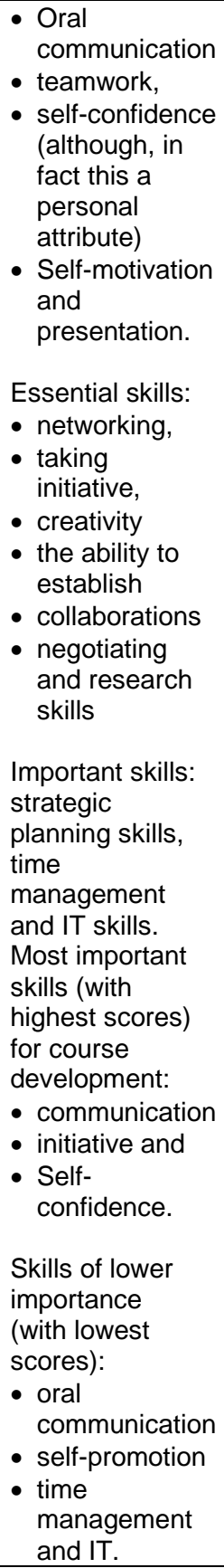 & 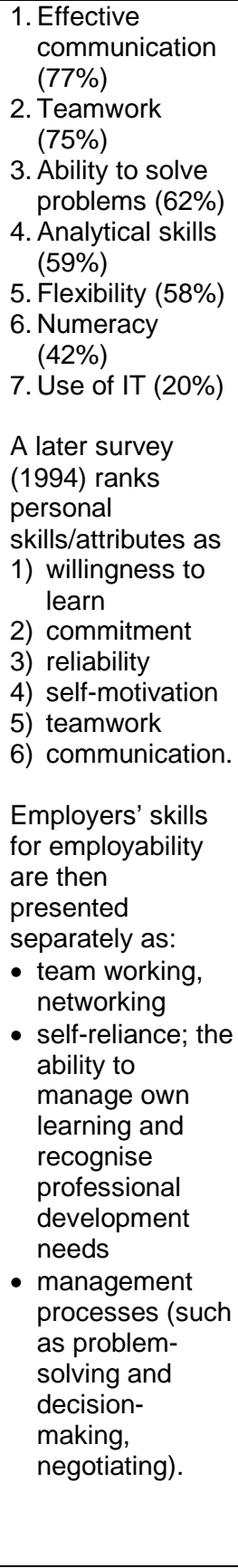 \\
\hline
\end{tabular}


Basic literacy and numeracy - includes reading, writing, speaking, listening and performing basic mathematical calculations. Graduates are competent to read when they are able to construe and undertand written information. writing refers to the competency to convey one's views or ideas through written material such a memos and reports. Numeracy skills refers to the competency of using diverse mathematical procedures to provide solutions.

- $\quad$ Critical thinking - refers to using intellectual or reasoning to bring about a needed change. Is needed in decision-making and addressing challenges and making the best out of challenging situations.

- $\quad$ Management - include the ability to plan, organise, coordinate, facilitate activities to achieve pre-determined objectives.

- Leadership attributes - the ability to motivate and positively influence others to achieve organisational goals. Graduates should develop and lead individual or team activities, address challenging situations arising in the course of the implementation of activitites.

- Interpersonal attributes - refers to graduate's competency to relate positively with other members of the group, support other team members' learning, manage conflicts, and perform well in a culturally diverse environment. It also include the ability to work comfortably with members of the team at different levels of an organization.

- Information technology (IT) - refers to the use of technology that contributes to the effective execution of tasks. This includes the ability to use computer devices and applications to communicate and execute tasks.

- $\quad$ Systems thinking - refers to the ability to comprehend interface of systems such as functions of different departments in an organisation, or linkages between applications within a computerized system, different subsets of society in relation to political and socio-economic setup, including the economics of the world.

- Work ethic - includes the graduate's attitude and character towards the job. This includes being present, beginning work on time, enthusiasm, completing assigned tasks on time, trustworthiness, tolerance, reliability, professional conduct, and eagerness to learn and further the career.

These employability attributes seem to be congruent, less complex, easy to explain, and more generally agreed upon by various authors. Therefore, this article's quest - to determine stakeholders' perspectives on employability attributes in Namibia - has been aligned to the above dimensions. 


\section{METHODOLOGY}

A quantitative approach using a survey method was employed (Creswell 2003). A questionnaire adapted from Rosenberg et al. (2012), containing 51 items, was administered to management sciences graduates from HEIs in Namibia who had less than two years of employment after graduation, management sciences lecturers, and employers. The questionnaire contained demographic questions as well as those to obtain nominal data by a five-point Likert scale (strongly agree, agree, neutral, disagree, and strongly agree). The reliability of the questionnaire was tested using Cronbach’s alpha technique scoring .925, which indicates that dependability of the instrument is excellent. The study employed a purposeful sampling technique to select management sciences graduates and lecturers from HEIs in Namibia. The study further employed snowball sampling to select employers of these graduates. The sample size for each group was determined using a sampling table calculated with the Krejcie and Morgan formula $s=X^{2} N P(1-P) \div d^{2}(N-1)+X^{2} P(1-P)$. The formula was found to be the most appropriate as it has a 95 per cent confidence level, and a 5 per cent margin of error (Krejcie and Morgan 1970). Using the formula, the researcher distributed survey questionnaires to 135 graduates, 35 lecturers, and 50 employers. Of these, 80 completed questionnaires were returned by graduates, 23 by lecturers, and 39 by employers.

Data were analysed with the help of IBM Statistical Package for Social Sciences (SPSS) version 24. Analysis was done in the form of descriptive statistics using frequencies and percentages. Categorical variables were also generated to ascertain the difference in responses between the groups of participants, i.e. lecturers, graduates and employers.

\section{RESULTS AND DISCUSSION}

The results are presented in summaries of percentages for each of the eight categories of graduate employability attributes as follows:

\section{Basic literacy and numeracy attributes}

Results on basic literacy and numeracy attributes indicate that 90 per cent of graduates and employers perceive these attributes to be important for job performance, compared to about 70 per cent of management sciences lecturers. Graduates and employers also strongly agree that these are included in the curriculum. Although less than 50 per cent of the graduates indicated that they need remedial training in this attribute, about 75 per cent of lecturers and employers thought that graduates do indeed need remedial training in this attribute. Graduates think they need less training than do employers. 


\section{Critical thinking attributes}

Ninety per cent of graduates and employers share the opinion that critical thinking is needed for graduate job performance, compared to only 63 per cent of lecturers. This shows a difference in opinion between employers and lecturers. Only 50 per cent of the lecturers are in agreement that critical thinking is emphasised in management sciences curricula in Namibia. This shows uncertainty as to whether critical thinking is indeed emphasised in curricula. Both lecturers and employers $(70 \%)$ considered that graduates need more training on critical thinking after graduation. This is in contrast to the opinion of less than 50 per cent of graduates.

\section{Interpersonal attributes}

Interpersonal attributes were considered essential for job performance by graduates and employers with 96 per cent and 87 per cent respectively, while more than 30 per cent of lecturers did not consider these as important for job performance. Moreover, only 50 per cent of management sciences lecturers were certain that interpersonal attributes are emphasised in management sciences programme curricula. More than 60 per cent of employers and about half of graduates and lecturers indicated that more training is required in this attribute.

\section{Leadership attributes}

About 43 per cent lecturers did not agree that leadership attributes are needed by graduates to perform in their jobs. By contrast, just less than 10 per cent of the graduates and employers shared this opinion. Half of the lecturers indicated that the curricula do not emphasise leadership attributes. About 70 per cent of employers indicated that more leadership training is required, while just over half of graduates did not think that they need more leadership training.

\section{Management attributes}

Only 4 per cent and 10 per cent of graduates and employers respectively, and more than 40 per cent of lecturers thought that management attributes are not needed for graduate job performance. However, 85 per cent, 60 per cent and 75 per cent of graduates, lecturers and employers, respectively, indicated that the curriculum does include management aspects. This shows that there are more employers who think that the university can do more to enhance management attributes. About 60 per cent of lecturers and 75 per cent of the employers opined that graduates need more training on management skills. 


\section{Information technology attributes}

Respondents indicated that IT skills are needed for graduate job performance. Specifically, 91 per cent of graduates, 73 per cent of lecturers, and 75 per cent of employers were in agreement. Respondents also agreed that to a certain extent, the curricula places an emphasis on IT. However, about 85 per cent employers indicated that more training is required in this regard, with 61 per cent of lecturers and 55 per cent of graduates being in agreement.

\section{Systems thinking attributes}

Close to 90 per cent of employers were certain that graduates need systems thinking attributes to excel in their jobs, with 82 per cent of graduates and 60 per cent of the lecturers agreeing. Less than 60 per cent of the lecturers indicated that systems thinking training is included in curricula and more than 80 per cent of the employers thought that more training in this attribute is required when graduates enter the workforce.

\section{Work ethics}

Only about 60 per cent of the graduates and 66 per cent of the lecturers considered work ethics as important for job performance. Employers seem to consider this attribute more important than lecturers and graduates, with 81 per cent indicating the importance of work ethics. Less than 60 per cent of the lecturers and graduates indicated that work ethics are included in management sciences curriculum. More lecturers (74\%) and employers (72\%) called for more training on work ethics, with half of graduates being in agreement.

In general, lecturers are not assertive with regard to attributes that are important for job performance and are uncertain whether the curricula does indeed emphasise such attributes. However, they were of the opinion that more training should be provided to graduates. The graduates felt that they needed less remedial training in all attributes and rated themselves very highly as compared to lecturers and employers. They thought that the attributes they possess had been aquired as a result of their participation in the degree programme. On the other hand, employers expressed a strong position in terms of the importance of employability attributes for job performance and asserted that graduates need more remedial training in the graduate attributes.

\section{Prioritisation of graduate employability attributes needed by management sciences graduates}

Table 2 shows how respondents prioritised the graduate employability attributes needed in management sciences curricula. 
Both graduates and employers considered management attributes highly important, while lecturers prioritised IT as most important. Graduates further prioritised interpersonal attributes. The least important attributes were rated by graduates as work ethics, lecturers critical thinking, and employers IT. This ranking of attributes depicts the mismatch in priorities between stakeholders.

Table 2: Ranking of attributes by importance for job performance

\begin{tabular}{|c|l|l|l|}
\hline Rank & \multicolumn{1}{|c|}{ Graduates \% } & \multicolumn{1}{c|}{ Lecturers \% } & \multicolumn{1}{c|}{ Employers \% } \\
\hline 1 & Interpersonal 95.8 & IT 72.8 & Management 90.3 \\
\hline 2 & Literacy and Numeracy 94.6 & Literacy and numeracy 68.2 & Critical thinking 89.0 \\
\hline 3 & Critical thinking 94.2 & Interpersonal 67.1 & Systems thinking 88.7 \\
\hline 4 & Leadership 93.9 & Work ethics 66.2 & Literacy and numeracy 87.0 \\
\hline 5 & IT 90.8 & Critical thinking 63.5 & Interpersonal 86.8 \\
\hline 6 & Systems thinking 81.6 & Systems thinking 59.1 & Leadership 85.7 \\
\hline 7 & Work ethics 59.1 & Leadership 56.6 & Work ethics 81.1 \\
\hline 8 & - & Management 55.0 & IT 74.6 \\
\hline
\end{tabular}

\section{Other important employability attributes}

The questionnaire encompassed an open-ended question for survey participants to add any other attribute that they perceived to be important for job performance and that should be emphasised in management sciences curricula. See Figure 1 for the attributes generated by respondents.

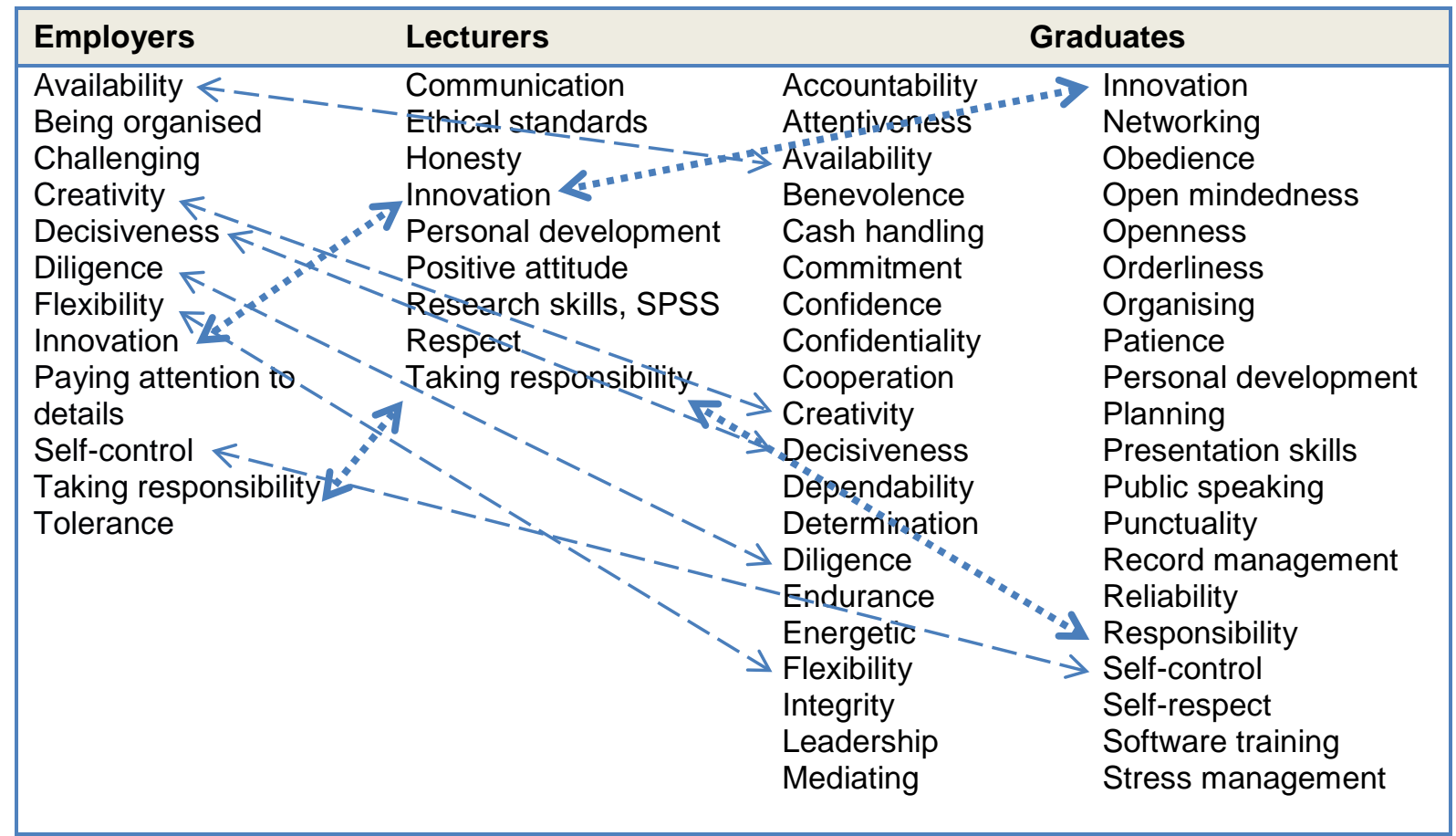

Figure 1: Graduate employability attributes generated by employers, lecturers, and graduates 
From Figure 1, there seems to be areas of similarity. Specifically, employers, lecturers, and graduates listed innovation as an important aspect. This implies that the university should teach students how to be innovative. Another attribute held in common is taking responsibility for outcomes. To a large extent, graduates seemed to be more aware of what employers want than the lecturers. The lists generated above are similar to lists generated by studies elsewhere, which provokes the question of whether employability attributes for management sciences are universal.

\section{CONCLUSION}

The aim of the article was to provide an analysis of the graduate attributes needed in Namibia as perceived by graduates, employers and lecturers, using the discipline of management sciences as a case. The article focused on graduate employability attributes, which are qualities and skills beyond the subject-specific skills. Employers have expressed concern over the lack of these attributes among the graduates in Namibia. The first step was then to determine the perceptions of the stakeholders using a survey.

The findings have indicated a mismatch between the perceptions of the stakeholders with regard to the graduate attributes regarded as essential for performing a job performance, those that are emphasised in curricula, and those in which graduates will require more training. A difference was found in the priorities of employers, HEIs and graduates regarding employability attributes. This means that HEIs in Namibia are not responding to the hiring needs of the management sciences labour market because they are not emphasising the development of employability attributes. As a result, apart from disciplinary knowledge, graduates leave university with inadequate training on employability attributes. The role of higher education is to produce graduates that can perform well in a 21st century workplace, which means that employability attributes should be emphasised. Graduates would like to leave university with the attributes needed by the contemporary labour market so that they can become productive members of the workforce, which will eventually lead to a competitive national economy.

This study has brought to light the employability attributes sought after by employers. HEIs should align curricula to enhance these attributes by working together with employers during curriculum development. Moroever, students should be sensitised as to which attributes are sought after by employers. The article argued that assessing the needs of higher education stakeholders provides an understanding of the scenario of graduate employability in a given context. Accordingly, the graduate attributes which should be enhanced through curricula were identified. This awareness may promote the need for HEIs and employers to engage and play a 
complementary role in developing graduate employability. Further research should determine how employability attributes are embedded in curricula and what possible approaches can be developed to enhance the required attributes in the curricula of management sciences. Furthermore, future research should assess whether graduate employability attributes for management sciences are universal across countries.

\section{REFERENCES}

Ahmadl, Esa, Padil Suhaili and Hassan Shariati. 2015. Perception lecturers of the soft skills of engineering students in Malaysian Polytechnics. Multidisciplinary Studies 2: 487-495.

Al-Harthi, Hamood K. 2011. University student perceptions of the relationship between university education and the labour market in Egypt and Oman. Prospects 41(4): 535-551. doi:10.1007/s11125-011-9216-4.

Barrie, Simon C. 2006. Understanding what we mean by the generic attributes of graduates. Sydney: University of Sydney.

Bridgstock, Ruth. 2009. The graduate attributes we've overlooked: Enhancing graduate employability through career management skills. Higher Education Research and Development 28(1): 31-44. doi:10.1080/07294360802444347.

Brown, R. 2007. Enhancing student employability?: Current practice and student experiences in HE performing arts. Arts and Humanities in Higher Education 6(1): 28-49. doi:10.1177/1474022207072198.

Cai, Yuzhuo. 2013. Graduate employability: A conceptual framework for understanding employers' perceptions. Higher Education 65(1): 457-469. doi:10.1007/s10734-012-9556-x.

Crebert, G., M. Bates, B. Bell, C. J. Patrick and V. Cragnolini. 2004. Developing generic skills at university, during work placement and in employment: Graduate's perceptions. Higher Education Research and Development 23(2): 147-165. doi:10.1080/0729436042000206636.

Creswell, John W. 2003. Research design. In Research design: Quantitative, qualitative, and mixed methods approaches, 1-26. $2^{\text {nd }}$ Edition. London: Sage Publications. https://isites.harvard.edu/ fs/docs/icb.topic1334586.files/2003_Creswell_A Framework for Design.pdf.

Fincher, Mark. 2007. Governments as human capital providers: A rationale for strong government support of broad higher education access. Competitiveness Review: An International Business Journal 17(1): 67-76. doi:10.1108/10595420710816623.

Griesel, Hanlie and Ben Parker. 2009. Graduate attributes: A baseline study on South African graduates from the perspective of employers. South African Qualifications Authority.

Hillage, J. and E. Pollard. 1998. Employability: Developing a framework for policy analysis. https://s3.amazonaws.com/academia.edu.documents/43539201/Employability_Developing_a_fra mework_for20160309-24658-1ix1nw2.pdf?AWSAccessKeyId=AKIAIWOWYYGZ2Y53UL3A \&Expires $=1519668812 \&$ Signature=txf2prQfak3C0gY8rN5iqz7xKbw\%3D\&response-contentdisposition=inline\%3B\%20filename\%3DEmployability_developing_a_framework_for.pdf

Hodges, Dave and Noel Burchell. 2003. Business graduate competencies: Employers' views on importance and performance. Asia-Pacific Journal of Cooperative Education 4(2): 16-22.

Husein, Mohd Yusof, Seri Bunian Mokhtar, Abdul Aziz Ahmad and Ramlee Mustapha. 2010. Importance of employability skills from employers' perspective. Procedia: Social and Behavioral Sciences 7(2): 430-438. doi:10.1016/j.sbspro.2010.10.059.

Jonck, Petronella. 2014. A human capital evaluation of graduates from the faculty of management sciences employability skills in South Africa. Academic Journal of Interdisciplinary Studies 3(6): 265-274. doi:10.5901/ajis.2014.v3n6p265. 
Kaplan, Robert and David Norton. 2004. Measuring the strategic readiness of intangible assets. Harvard Business Review. https://hbr.org/2004/02/measuring-the-strategic-readiness-of-intangible-assets

Kennedy, Sophie. 2010. Infusing critical thinking into an employability skills program: The effectiveness of an immersion approach. Edith Cowan University.

Krejcie, Robert V. and Daryle W. Morgan. 1970. ACTIVITIES. Educational and Psychological Measurement 38: 607-610.

Links, Frederico. 2010. Namibia's skills deficits: Cross-sectoral perceptions and experiences. Windhoek: Namibia Employers Federation.

Lowden, Kevin, Stuart Hall, Dely Elliot and Lewin Jon. 2011. Employers' perceptions of the employability skills of new graduates. University of Glasgow.

Markes, Imren. 2006. A review of literature on employability skill needs. European Journal of Engineering Education 31(6): 637-650.

Marope, Mmantsetsa Toka. 2006. Namibia human capital and knowledge development for economic growth with equity. Africa Region Human Development: Working Paper Series No. 84. http://siteresources.worldbank.org/INTAFRICA/Resources/No84.pdf

Martin, Rob, Frank Villeneuve-smith, Liz Marshall and Ewan Mckenzie. 2008. Employability skills explored employability skills. London.

Melink, Mateja and Samo Pavlin. 2012. Employability of graduates and higher education management systems. Final Report of DEHEMS Project. University of Ljubljana. http://www.dehemsproject.eu/static/uploaded/files/files/resoults/DEHEMS_REPORT_final.pdf

Moreau, Marie-Pierre and Carole Leathwood. 2006. Graduates' employment and the discourse of employability: A critical analysis. Journal of Education \& Work 19(4): 305-324. doi:10.1080/13639080600867083.

Morrison, Andrew. 2014. A class act? Lecturers' views on undergraduates' employability. British Journal of Sociology of Education 35(4): 487-505. doi:10.1080/01425692.2013.802420.

National Council for Higher Education. 2011. Tracer study of graduates from higher education institutions 1999-2008. Windhoek.

National Planning Commission. 2010. National Human Resources Plan. Windhoek: Government of the Republic of Namibia.

Omar, Nik Hairi, Azmi Abdul Manaf, Rusyda Helma Mohd, Arena Che Kassim and Khairani Abd Aziz. 2012. Graduates' employability skills based on current job demand through electronic advertisement. Asian Social Sciences 8(9): 103-111. doi:10.5539/ass.v8n9p103.

Rosenberg, Stuart, Ronald Heimler and Elsa-Sofia Morote. 2012. Basic employability skills: A triangular design approach. Education + Training 54(1): 7-20. doi:10.1108/00400911211198869.

Rospigliosi, Asher Pericles, Sue Greener, Tom Bourner and Maura Sheehan. 2014. Human capital or signalling: Unpacking the graduate premium. International Journal of Social Economics 41(5): 420-432. doi:10.1108/IJSE-03-2013-0056.

Schade, By Klaus and Taimi Amunkete. 2011. Democracy report: Namibia Labour Force Survey 2008. Windhoek.

Tempone, Irene, Marie Kavanagh, Naomi Segal, Phil Hancock, Bryan Howieson, Jenny Kent, Irene Tempone, et al. 2012. Desirable generic attributes for accounting graduates into the twenty-first century: The views of employers. Accounting Research Journal 25(1): 41-55. doi:10.1108/10309611211244519.

Tomlinson, Michael. 2008. 'The degree is not enough': Students' perceptions of the role of higher education credentials for graduate work and employability. British Journal of Sociology of Education 29(1): 49-61. doi:10.1080/01425690701737457.

Tran, Thi Tuyet. 2016. Enhancing graduate employability and the need for university enterprise collaboration. Journal of Teaching and Learning for Graduate Employability 7(1): 58-71. doi:10.21153/jtlge2016vol7no1art598. 
Tymon, Alex. 2013. The student perspective on employability. Studies in Higher Education 38(6): 841856. doi:10.1080/03075079.2011.604408.

Weber, Sylvain. 2014. Human capital depreciation and education level. International Journal of Manpower 35(5): 613-642. doi:10.1108/IJM-05-2014-0122.

Wickramasinghe, Vathsala and Lasantha Perera. 2010. Employers' perceptions towards employability skills. Education + Training 52(3): 226-244.

Wimalasiri, H. S. 2015. 'Employer's perception on employability skills and attitudes of new graduates'. Qualitative insights from the employers in Sri Lanka Hashan. Asian Journal of Multidisciplinary Studies 3(11): 112-120.

Wye, Chung-Khain and Yet-Mee Lim. 2009. Perception differential between employers and undergraduates on the importance of employability skills. International Education Studies 2(1): 95-105.

Yorke, Mantz. 2006. Employability in higher education: What it is - What it is not. Learning and Employability. Heslington, UK: The Higher Education Academy. 